Selcuk Journal of Agriculture and Food Sciences

http://sjafs.selcuk.edu.tr/sjafs/index

Research Article
SJAFS

(2020) 34 (2), 137-140

e-ISSN: $2458-8377$

DOI:10.15316/SJAFS.2020.207

\title{
Investigation of Insulin-Like Growth Factor Binding Protein 3 (IGFBP-3) Polymorphism in Anatolian Black and Holstein Friesian Cattle Breeds*
}

\author{
(D)Marwan FADHIL ${ }^{1, *}$, (Dỉbrahim AYTEKIN ${ }^{1}$, (D) Uğur ZÜLKADIR ${ }^{1}$ \\ ${ }^{1}$ Selçuk University, Faculty of Agriculture, Department of Animal Science, Konya, Turkey
}

\begin{tabular}{l}
\hline ARTICLE INFO \\
\hline Article history: \\
Received date: 28.03 .2020 \\
Accepted date: 16.05 .2020 \\
\hline Edited by: \\
Duran YAVUZ; Selçuk University, \\
Turkey \\
Reviewed by: \\
Yasemin GEDIK; Ankara University, \\
Turkey \\
Taki KARSLI; Akdeniz University, \\
Turkey
\end{tabular}

Keywords:

Anatolian Black

Holstein Friesian

IGFBP-3

PCR-RFLP

BsuRI

Polymorphism

\begin{abstract}
Insulin-like growth factor binding protein-3 (IGFBP-3) gene is a structural gene which is associated with development and growth in livestock. The present study aimed to investigate the polymorphisms of IGFBP-3 gene in Holstein Friesian (HF) and Anatolian Black (AB) cattle breeds. BsuRI (GG $\downarrow$ CC) restriction enzyme was used to detect of IGFBP-3 gene polymorphism. Although Anatolian Black breed was monomorphic (AA genotype), three genotypes (AA, AB and $\mathrm{BB}$ ) were detected in Holstein Friesian breed by digestion of PCR products with BsuRI. The A and B allele frequencies were 0.57 and 0.43 , respectively, in Holstein Friesian breed, while A allele frequency was 1.00 in Anatolian Black breed. $\mathrm{AA}, \mathrm{AB}$ and $\mathrm{BB}$ genotype frequencies were $0.32,0.50$ and 0.18 , respectively in the Holstein Friesian breed. All three possible genotypes weare detected in Holstein Friesian breed. In the analysis made taking into account Hardy-Weingberg equilibrium, significant deviation was not observed in terms of genotype distributions $(\mathrm{P}>0.05)$. In other words, the Holstein Friesian cattle population was found in the Hardy-Weinberg equilibrium.
\end{abstract}

\section{Introduction}

Improvement of livestock has focused on the selective breeding of individuals with superior phenotypes. With the development of increasingly advanced statistical methods that maximize selection for genetic gain, this simple approach has been extremely successful in increasing the quantity of agricultural output (Williams, 2005). Milk production is a quantitative trait which is affected by many environmental factors and controlled by many genes (Zhang et al., 2006). Several candidate genes have been identified that affect the productivity of cattle (Fadhil and Zülkadir, 2017; Aytekin and Boztepe, 2013). One of these genes is IGFBP-3. IGFBP-3 is a family of proteins that are a fundamental part of the Insulin-like Growth Factors (IGFs) system (Sudhakar, 2009) and plays a key role in regulating the biological activities of IGFs (Zhang et al., 2006). The IGFBP-3 gene is mapped on chromosome 4 in bovine genome (Priyadi, 2017). The mRNA of IGFBP-3 gene is length 8.407 bp containing 4 non-

\footnotetext{
*Corresponding author email: mervan.bayraktar@gmail.com

* Short communication
}

coding introns and 5 coding exons (Othman, 2014). The polymorphim of IGFBP-3 gene was identified for the first time by Maciulla (1997). Zhang et al. (2006), reported that IGFBP-3 gene affects milk yield at 305 days and protein percentage in Chinese Holstein cattle breed. In addition, it has been reported that IGFBP-3 gene affects serum IgG levels (Choudhary et al. 2006; Choudhary et al. 2007). According to previous studies the IGFBP-3 gene can be used as candidate gene for milk and growth traits. Today, restriction enzyme polymorphisms are commonly used for different candidate genes in many livestock species such as cattle (Saleh et al. 2019; Karsl1 2019), goat (Demir et al. 2020), sheep (Ali et al. 2009; Qureshi et al. 2014) and chicken (Karsli et al. 2017).

The aim of this study was to determine the InsulinLike Growth Factor Binding Protein-3 (IGFBP-3) gene polymorphism by using BsuRI (HaeIII) restriction enzyme in both Anatolian Black and Holstein Friesian cattle breeds.

\section{Materials and Methods}


In this study, a total of $50(\mathrm{AB})$ and $50(\mathrm{HF})$ cattle breeds were used for IGFBP-3 gene. Disodium EDTA containing tubes were used to prevent coagulation of blood during collection of samples. Then, blood samples storage was carried out at $-20{ }^{\circ} \mathrm{C}$ until DNA extraction procedures. Blood samples were taken from the Tail Vein of animals. Genomic DNA was extracted from whole blood using the Quick Gene DNA whole blood kit S (DB-S) (KURABO, Japan). 651 bg length of IGFBP-3 gene region was amplified with forward (5'-CCAAGCGTGAGACAGAATAC-3') and reverse (5'-AGGAGGGATAGGAGCAAGTT-3') primers reported by Maciulla et al. (1997). The PCR was done in a reaction volume of $10 \mu \mathrm{L}$ according with some modifications. The reaction consists of $5 \mu \mathrm{L}$ of $2 \mathrm{X}$ Dream Taq Green PCR Master Mix (Thermo Scientific, USA), $0.30 \mu \mathrm{L}$ primer each primer forward and reverse $(10 \mathrm{pmol})$ (Macrogen, Turkey) and $3.4 \mu \mathrm{L}$ ddH2O which finally added to $1 \mu \mathrm{L}$ genomic DNA. The cycling protocol followed with initial denaturation at $94^{\circ} \mathrm{C}$ for $5 \mathrm{~min}$ followed by 35 cycles of denaturation at $94{ }^{\circ} \mathrm{C}$ for $1 \mathrm{~min}$, annealing at $60^{\circ} \mathrm{C}$ for $1 \mathrm{~min}$, extension at $72{ }^{\circ} \mathrm{C}$ for $1 \mathrm{~min}$ with a final extension at $72^{\circ} \mathrm{C}$ for $5 \mathrm{~min}$. The PCR product of each sample $(5 \mu \mathrm{L})$ and 100 bp DNA ladder (Vivantis, Malaysia) were loaded in $2 \%(\mathrm{w} / \mathrm{v})$ agarose gels in $0.5 \mathrm{X}$ Tris-Borate-EDTA (TBE) buffer staining using ethidium bromide. The electrophoresis was carried out for $45 \mathrm{~min}$ at $100 \mathrm{~V}$. The electrophoresis gel was examined on an UV transilluminator and bands were visualized and photographed. The PCR products of IGFBP-3 gene were cleaved by fast digest; amplified fragments were digested with BsuRI (Thermo Scientific, \#FD0154) at $37^{\circ} \mathrm{C}$. The reaction volume was $15 \mu \mathrm{L}$ consisted of 5 $\mu \mathrm{L}$ PCR product, $8.5 \mu \mathrm{L}$ ddH2O, $1 \mu \mathrm{L} 10 \mathrm{X}$ buffer and $0.5 \mu \mathrm{L}$ restriction enzyme. The polymorphism of the cleaved fragments recognition was carried out by $\% 2$ agarose gel electrophoresis then the digested PCR products was obviously envisioned under UV light and scored in a gel documentation system.

\section{Results and Discussion}

A total of three genotypes including AA (199 and $164 \mathrm{bp}), \mathrm{BB}$ (215 and $164 \mathrm{bp})$ and $\mathrm{AB}$ (215, 199 and 164) (Figure 1 and 2) were detected by digestion of 651 bp of IGFBP-3 gene region with BsuRI restriction enzyme. Additionally, 164 and 154 bp fragments were observed on agarose gel as a thick band for all genotypes. The allele and genotype frequencies of each breed are given in Table 1 . The results showed differences between the two breeds where the Anatolian black cattle showed one genotype while the Holstein Friesian showed three genotypes. This means that the $\mathrm{AB}$ cattle breeds maintains its genetic structure compared to Holstein Friesian breeds. The reason may be that $\mathrm{AB}$ is not subject to migration, gene flow, admix- ture, mutation or selection. The genotype frequencies of IGFBP-3 gene in Holstein Friesian are agreement to Hardy-Weinberg equilibrium $(\mathrm{P}>0.05)$. Sun et al. (2002) investigated the relationship between IGFBP-3 gene polymorphism and the beef performance in Qinchuan cattle. The frequency of $\mathrm{AA}, \mathrm{AB}$ and $\mathrm{BB}$ genotypes were found to be $0.70,0.28$ and 0.02 and the allele frequencies were 0.84 and 0.16 for $\mathrm{A}$ and $\mathrm{B}$ respectively. The result showed that eye muscle area of AA genotype was significantly higher than BB genotype $(\mathrm{P}<0.05)$ and beef fat content of $\mathrm{AB}$ and $\mathrm{BB}$ genotypes were significantly higher than AA. Choudhary et al., (2007) studied polymorphism of IGFBP-3 gene and its association with birth weight and body weight in Hariana, Holstein Friesian and their crossbreds. The frequency of $\mathrm{AA}, \mathrm{AB}$ and $\mathrm{BB}$ genotypes was $0.65,0.32$ and 0.03 in crossbreds and $0.29,0.65$ and 0.06 in Holstein Friesian respectively. The allelic frequency of the $\mathrm{A}$ and $\mathrm{B}$ allele was 0.81 and 0.19 in crossbreds and 0.62 and 0.38 in Holstein Friesian respectively.

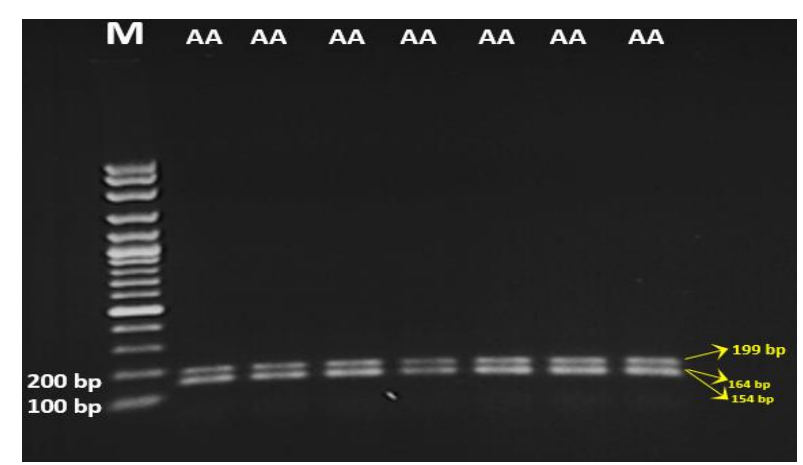

Figure 1

Agarose gel electrophoresis of digested products of IGFBP-3 gene with BsuRI restriction enzyme in Anatolian Black cattle; M: 100 bp Plus DNA Ladder ( $V i$ vantis Technologies), AA: 199 and 164 bp

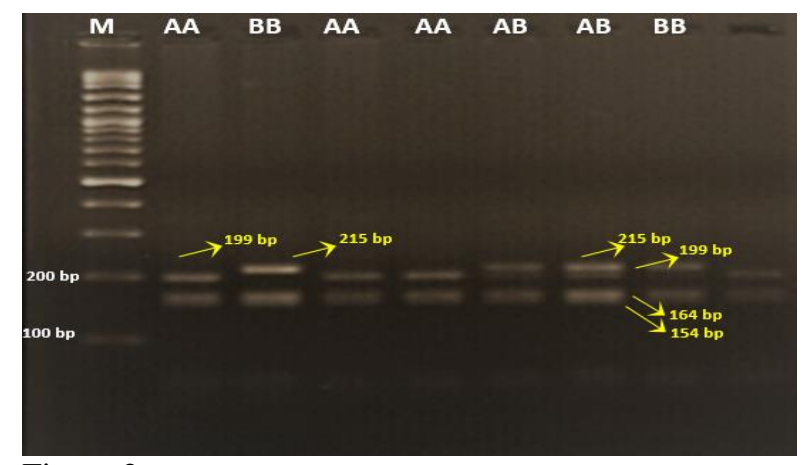

Figure 2

Agarose gel electrophoresis of digested products of IGFBP-3 gene with BsuRI restriction enzyme in Holstein Friesian cattle; M: 100 bp Plus DNA Ladder (Vivantis Technologies), AA: 199 and 164; BB: 215 and $164 \mathrm{bp}$; AB: 215, 199 and $164 \mathrm{bp}$ 
Table 1

Allele and genotype frequencies at IGFBP-3 gene in two cattle breeds

\begin{tabular}{lccccccc}
\hline \multirow{2}{*}{ Breed } & \multirow{2}{*}{$\mathrm{N}$} & \multicolumn{3}{c}{ Genotype frequencies } & \multicolumn{2}{c}{ Allele frequencies } & \multirow{2}{*}{$\chi^{2}$ and P } \\
\cline { 2 - 6 } & & $\mathrm{AA}$ & $\mathrm{AB}$ & $\mathrm{BB}$ & $\mathrm{A}$ & $\mathrm{B}$ & - \\
\hline $\mathrm{AB}$ & 50 & 1.00 & 0.00 & 0.00 & 1.00 & 0.00 & $0.03(\mathrm{P}>0.05)$ \\
\hline $\mathrm{HF}$ & 50 & 0.32 & 0.48 & 0.20 & 0.56 & 0.44 & \\
\hline $\mathrm{AB} \cdot$ Anatolian Black; & $\mathrm{HF} \cdot$ Holstein Friesian; $\mathrm{P}>0.05 \cdot$ in Hardy-Weinberg equilibrium & & &
\end{tabular}

AB: Anatolian Black; HF: Holstein Friesian; P>0.05: in Hardy-Weinberg equilibrium

Association analysis results showed that a significant effect $(\mathrm{P}<0.05)$ of genotypes on birth weight and body weight (weight at 12,18 and 24 months of age) of the animals. Animals with AB genotype showed higher birth weight and body weight than the animals with AA genotype. Zhang et al., (2006) investigated association between IGFBP-3 gene polymorphisms and milk traits in Chinese Holstein. It was reported A and B allele frequencies for IGFBP-3 gene were 0.574 and 0.426 , respectively in Chinese Holstein population. The genotypes of animals at IGFBP-3 locus significantly affected 305-day standard milk yield, protein percentage and somatic cell score. The B allele increased the milk yield, while the $\mathrm{AB}$ genotype had a higher protein percentage than AA and BB. Othman et al. (2015) determined the genetic polymorphism of IGFBP-3 gene in Egyptian cattle breeds. The restriction patterns of IGFBP-3/HaeIII showed that forty-six examined animals were genotyped as $\mathrm{AA}, \mathrm{CC}$ and $\mathrm{AC}$ with frequencies of $0.21,0.21$ and 0.56 respectively.

The previous studies mentioned above imply that IGFBP-3 polymorphism may be used for growth, development, body weight, milk yield, reproduction, immunity, metabolism, and energy balance in cattle. Hence, the present study provides baseline data for future genetic assessments of these populations. The results of the present study revealed that IGFBP-3 polymorphism may be used to improve meat properties and growth characteristics in Holstein Friesian in the future, while it cannot be used for Anatolian Black due to deficiency of diversity. This study is also important in determining the status of these two breeds raised in Turkey and to shed light on those who will work on this area in the future.

\section{Acknowledgements}

We thank BAP Coordinatorship of Selçuk University for supporting this study with no. 17401120 project. Authors have an equal contribution rate in the research. There is no conflict of interest.

\section{References}

Ali BA, El-Hanafy, AA, Salem, HH (2009). Genetic biodiversity studies on IGFBP-3 gene in Egyptian sheep breeds. Biotechnology in Animal Husbandry 25: 101-109.

Aytekin I, Boztepe S (2013). Associations of Pit-1 Gene Polymorphism with Milk Yield and Composition Traits in Brown Swiss Cattle. J Anim Plant Sci 23: 1281-1289.
Choudhary V, Kumar P, Saxena VK, Bhattacharya TK, Bhushan B, Sharma A, Ahmed KA (2006). Effect of Leptin and IGFBP-3 Gene Polymorphisms on Serum IgG Level of Cattle Calves. AsianAustralasian Journal of Animal Sciences 19: 10951099.

Choudhary V, Kumar P, Bhattacharya TK, Bhushan B, Sharma A, Shukla A (2007). DNA Polymorphism of Insulin-Like Growth Factor-Binding Protein-3 Gene and Its Association with Birth Weight and Body Weight in Cattle. Journal of animal breeding and genetics 124: 29-34.

Demir E, Karslı BA, Karslı T, Balcioğlu MS (2020). Determination of SacII and MboII polymorphisms in the Nerve Growth Factor (NGF) gene in four native Turkish goat populations. Mediterranean Agricultural Sciences 33: 145-148.

Fadhil M, Zülkadir U (2017). Molecular Characterization of MSTN Gene in Holstein Friesians and Brown Swiss Cattle Breeds. Selçuk Tarım ve Gıda Bilimleri Dergisi 31: 151-153.

Karslı T, Balcioğlu MS, Demir E, Hüseyin Göktuğ F, Aslan M, Aktan S, Kamanlı S, Karabağ K, Şahin E (2017). Ankara Tavukçuluk Araştırma Enstitüsü'nde Yetiştirilen Yumurtacı Saf Tavuk Hatlarında Yumurta Verimi ile İlişkili IGF-I ve NPY Aday Genlerindeki Polimorfizmlerin Belirlenmesi. Türk - Tarım Glda Bilim ve Teknoloji Dergisi 5: 1051-1056.

Karslı T (2019). Türkiye'de Yetiştirilen Bazı Sığır Irklarında Asetil Koenzim A Dehidrogenaz Geni (g.2885C>A) Polimorfizminin ARMS-PCR Yöntemiyle Belirlenmesi. Lalahan Hayvancılık Araştırma Enstitüsü Dergisi 59: 25-29.

Maciulla JH, Zhang HM, DeNise SK (1997). A Novel Polymorphism in the Bovine Insulin-Like Growth Factor Binding Protein-3 (IGFBP3) Gene. Animal genetics 28: 375-375.

Othman EO, Sally SA, Sekena HA (2014). Single Nucleotide Polymorphism in Egyptian Cattle InsulinLike Growth Factor Binding Protein-3 Gene. Journal of Genetic Engineering and Biotechnology 12: 143-147.

Priyadi DA, Panjono P, Bintara S, Hartatik T (2017). Genotype of Brahman and Brahman Cross Cattle based on SNP in Insulin-Like Growth Factor Binding Protein-3 (IGFBP-3) Gene Sequences. Biodiversitas Journal of Biological Diversity 18: 795 800.

Qureshi MI, Sabir J. SM, Mutawakil M. HZ, El Hanafy AA, Ashmaoui HE, Ramadan H, Ahmed MM 
(2014). Review of modern strategies to enhance livestock genetic performance: From molecular markers to next-generation sequencing technologies in goats. Journal of Food, Agriculture \& Environment, 12: 752-761.

Sudhakar A (2009). Molecular Polymorphism Analysis of Bmpr1b, Igfbp-3 and Pou1f1 Genes in Nilagiri and Mecheri Sheep (Doctoral dissertation, Tamil Nadu Veterinary and Animal Sciences University).

Saleh AA, Rashad AM, Hassanine NN, Sharaby MA, Zhao Y (2019). Comparative analysis of IGFBP-3 gene sequence in Egyptian sheep, cattle, and buffalo. BMC research notes 12: 623 .
Sun WB Chen H, Lei XQ, Lei CZ, Zhang YH, Li RB, Zan LS, Hu SR (2003). Polymorphisms of insulin-like growth factor binding protein 3 gene and its associations with several carcass traits in Qinchuan cattle. Hereditas 25: 511-516.

Williams JL (2005). The Use of Marker-Assisted Selection in Animal Breeding and Biotechnology. Revue Scientifique et Technique-Office International des Epizooties 24: 379.

Zhang RF, Chen H, Lei CZ, Fang XT, Zhang YD, Hu SR, Su LH (2006). Association between PCRRFLP polymorphisms of five gene loci and milk traits in Chinese Holstein. Asian-Australasian Journal of Animal Sciences 20: 166-171. 